\title{
RECENT RESULTS OF IRRIGATION WATER ANALYSIS LOCATED MAINLY IN THE SOUTH-EASTERN PART OF HUNGARY
}

\author{
Judit Petö ${ }^{1 *}$, Attila Hüvely ${ }^{1}$, Krunoslav Mirosavljević ${ }^{2}$, Imre Cserni ${ }^{3}$ \\ 1Department of Agricultural Science, Faculty of Horticulture and Rural Development, John von Neumann \\ University, Kecskemét, Hungary \\ ${ }^{2}$ Biotechnical Department, University of Slavonski Brod, Slavonski Brod, Croatia \\ ${ }^{3}$ professor emeritus of the Faculty of Horticulture and Rural Development, John von Neumann University, \\ Kecskemét, Hungary \\ https://doi.org/10.47833/2020.3.AGR.001
}

\author{
Keywords: \\ Irrigation \\ Water analysis \\ Ground water \\ Soluble salt content \\ Nitrate level
}

$\begin{array}{ll}\text { Article history: } \\ \text { Received } & 29 \text { Sept } 2020 \\ \text { Revised } & 18 \text { Oct } 2020 \\ \text { Accepted } & 25 \text { Oct } 2020\end{array}$

\begin{abstract}
Irrigation water sources with inadequate quality and contamination have negative impacts on cultivation and environment as well. In our study we emphasize that the quality of ground waters should be controlled and regularly monitored. We compared our results with our former studies. We showed that our present results - with some minor exceptions - are in accordance with former statements regarding concentration of the main chemical components and physical characteristics of the irrigation ground waters, derived from different depths and located mainly in the south-eastern part of Hungary.
\end{abstract}

\section{Introduction}

The importance of irrigation has increased in recent years due to extreme weather changes. Extreme weather events as a result of climate change, are more and more intense in our region. The long drought periods and the extremities of the intensity and distribution of precipitation over time, result unfavorable changes for most cultivated plants. To compensate this, the sufficient soil tillage probably will not be enough, but primarily expanding the irrigated farming can mitigate the negative effects of periods of water scarcity. A prerequisite for this is the right amount and quality of water to be available for farmers [5].

The problem is further complicated as irrigation demand of agriculture currently exceeds the opportunities of the present irrigation systems. Therefore, development of these, i.e. via construction of new irrigation canals, is necessary.

The proportion of irrigated areas is low in Hungary only about $3 \%$ of the cultivated lands, while this rate is over $8 \%$ in the EU. This may be the result of factors such as the fragmented farm structure, lack of producer co-operations and short-term leases [12]. There is a similar situation in neighbouring countries. For example, in 2003 , Croatia irrigated only $0.86 \%$ of cultivated lands. Current proportion in 2020 is $2.4 \%$. Positive direction is clear but the dynamics is far too slow to meet the demands of modern agriculture [11].

However, four-fifths of the irrigated area is located in the Great Plain. In Hungary, vast majority of the irrigated areas are irrigated by farmers with surface waters. In Bács-Kiskun county the ratio of the groundwater use is higher, and increases further significantly regarding horticulture, especially vegetable growing $[1,8,12]$.

\footnotetext{
* Corresponding author. Tel.: +36 76517661

E-mail address: peto.judit@kvk.uni-neumann.hu
} 
The region of our experiments is mainly located in the south-eastern part of Hungary, in BácsKiskun county. This area is one of the most productive areas of the country, and accepted as the center of horticultural growing. The strengthening of the Mediterranean character of climatic conditions combined with sandy soils also contributes to the unfavorable change in soil moisture, and the importance of irrigation in our areas for crop safety is further increasing. With good management, efforts must be made to maintain and increase the water retention and storage capacity and potential of the soil. Sandy soils located here have low moisture-holding field capacities, so irrigation significantly increases crop yields and quality. Water sources are often used for liquid fertilizer application, as well.

In our study, we analyzed irrigation water samples from different subsurface layers. Groundwaters are more stable in most conditions and so they can be used more safely in usual, than surface water. However, the upper layer of groundwaters can be contaminated with substances of natural or artificial origin, as well as by easily soluble chemicals which penetrate into the lower soil layers. These contaminants can enter the aquifer system and eventually into private wells. Good quality of water used for irrigation is essential for economical crop yields and quantities, maintaining soil productivity and protecting the environment. On the other side, the physical and mechanical properties of the soil, the structure and permeability of the soil for ions present in irrigation waters are factors that should be taken into consideration $[2,13,15]$.

We followed water soluble salt content at first. High salt concentration that we have shown formerly in the irrigation water and/or in the soil in our region, may degrade the land, pollute groundwater and negatively affect crop yields. In our former study we followed water-soluble salinity in the soil of granted plantations of vineyards. Salt levels in our samples remained well below the threshold value, so it had no risk, from this point of view $[17,18]$.

Other parameters, like $\mathrm{pH}$, macro- and microelements and main anions were also analyzed, especially focusing on nitrate content. High nitrate content in waters causes problems in many countries of the EU, and the preventive measures and limit values must be kept to avoid the risk of nitrate pollution [10].

The additional aim of our present study was to compare present results with that of our former studies $[15,16]$.

\section{Materials and methods}

Collection of water samples. The collection of samples took place from ground waters, mainly by farmers. Samples were taken and analysed between 2016 and 2019 . Wells were located in the south-eastern part of the country, largely in the Danube-Tisza Interfluve. Depth of wells was in the scale from 5 to 275 meters. We divided the samples into three categories: Group 1: 5-30 meters, Group 2: 31-70 meters and Group 3: 71-275 meters. Number of the groundwater samples was 75, and the most of the samples fell in the middle range (Group 2, 49 samples). The rules of sampling were the following: collection of water sample from drilled wells after strong streaming for some minutes, and thoroughly washing out sample collection container with well-water, and prompt tight closing the vessel immediately after sampling. Samples were stored refrigerated before analysis. After a longer storage the results of the investigation were not reliable. Taking of samples and the scope of the tests were made taking into account the rules of the relevant legislations.

Water sample analysis. Analytical testing methods were made in the Soil and Plant Testing Laboratory of Faculty of Horticulture and Rural Development of John von Neumann University, by standard methods. Examination of $\mathrm{pH}$ was made by potentiometry, while electric conductivity (EC), reflecting soluble salt content, was measured with laboratory conductometer (Thermo Scientific).

Main macro- and microelement contents were measured by optical emission spectrometer (ICP-AES method). Main measured macro elements were $\mathrm{Ca}^{2+}, \mathrm{Mg}^{2+}, \mathrm{Na}^{+}, \mathrm{K}^{+}$. Among microelements $\mathrm{Fe}, \mathrm{Mn}$, and As were measured. $\mathrm{N}$ content of samples was determined in the form of the dominant inorganic ions. Ammonium and nitrate content were measured using FIA Star spectroscopic method. Among accompanying anions $\mathrm{PO}_{4}{ }^{3-}$ ions were analysed by ICP-OES method. Investigation of chloride was made by argentometric titration, whereas carbonate and hydrocarbonate ions were analysed by neutralization volumetry. The methods used are based on widely accepted standards. 
The number and the ratio of high concentrations of a component in irrigation water, were also estimated. We used the same limits that we used in our former studies, and based on technical directives, regulations and relevant literature data for common horticultural growing $[1,6,8,15,16$, $22,23]$. For estimating changes in the concentration of the nutrients Student's two-pair t-probe was applied. Relations between variables were estimated by calculating correlation coefficients, and statistically significant relationships were also emphasized, based on the widely available Critical Values for Pearson's Correlation Coefficient table (under 0.05, 0.01 and 0.001 levels) [7].

The results of these study were compared with the results of the former analysis based on 133 ground water samples deriving from this area.

\section{Results}

Chemical characteristic of the groundwater samples showed a slightly alkaline $\mathrm{pH}$. Most of the samples were in the 7-7.5 pH range, as shown in Table 1. Changes of alkalinity with depth was not significant. Alkalinity slightly exceeded 7.8 level in only two cases, once in the highest range and once in the deepest range, representing only $2.67 \%$ of the samples.

Regarding soluble salt content, average levels were shown declining with depth. The decrease in soluble salt content was significant (in $p<0.05$ level) but showed large variation.

Table 1. Average level and standard deviation of $\mathrm{pH}$ and $\mathrm{EC}$ with deepness of wells in three ranges

\begin{tabular}{|c|c|c|c|c|c|c|}
\hline & \multicolumn{2}{|c|}{$\mathbf{5 - 3 0} \mathbf{m}$} & \multicolumn{2}{c|}{$\mathbf{3 1 - 7 0} \mathbf{m}$} & \multicolumn{2}{c|}{$\mathbf{7 1 - 2 7 5} \mathbf{~ m}$} \\
\hline & average & SD & average & SD & average & SD \\
\hline $\mathbf{p H}$ & 7.25 & 0.25 & 7.19 & 0.24 & 7.32 & 0.28 \\
\hline $\mathbf{E C}, \boldsymbol{\mu S} / \mathbf{c m}$ & 1410 & 934 & 817 & 796 & 620 & 244 \\
\hline
\end{tabular}

Concentrations of the major cations generally were in the lower range (Fig. 1.). Levels of $\mathrm{Ca}^{2+}$, $\mathrm{Mg}^{2+}, \mathrm{Na}^{+}, \mathrm{K}^{+}$did not exceed the limit generally, but showed significant variation in the case of $\mathrm{Ca}^{2+}$, $\mathrm{Na}^{+}, \mathrm{K}^{+}$in the two upper range.

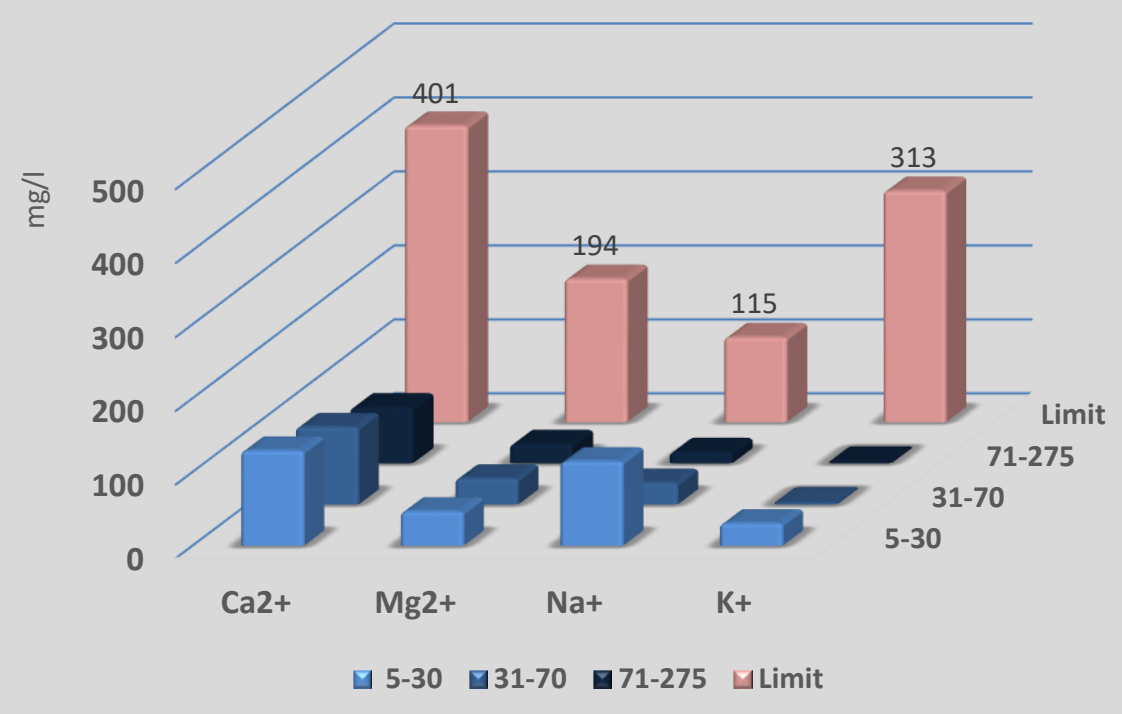

Figure 1. $\mathrm{Ca}^{2+}, \mathrm{Mg}^{2+}, \mathrm{Na}^{+}, \mathrm{K}^{+}$levels in samples in three depth categories 
The decrease of the level of these cations with depth was significant, mainly in the case of sodium and potassium $(p<0.01)$, and the level of these cations and depth was in strong correlation, as well. The occurrence of high macro element values in the samples was not significant (Table 2.).

Table 2. Occurrence of the critical values (expressed in \%) of the main cations in different depths

\begin{tabular}{|c|c|c|c|}
\hline & $\mathbf{5 - 3 0}$ & $\mathbf{3 1 - 7 0}$ & $\mathbf{7 1 - 2 7 5}$ \\
\hline & $\%$ & $\%$ & $\%$ \\
\hline $\mathbf{C a}^{2+}$ & 1.37 & 1.37 & 0 \\
\hline $\mathbf{M g}^{2+}$ & 0 & 0 & 0 \\
\hline $\mathbf{N a}^{+}$ & 6.85 & 2.74 & 0 \\
\hline $\mathbf{K}^{+}$ & 1.37 & 0 & 0 \\
\hline
\end{tabular}

Among anions, $\mathrm{HCO}_{3}{ }^{-}$ions were the dominant accompanying ions. The level of hydrocarbonate was the highest in the 5-30 m depth category (Fig. 2.). $\mathrm{Cl}^{-}, \mathrm{NO}_{3}{ }^{-}$and $\mathrm{PO}_{4}{ }^{3-}$ levels were the lowest in irrigation water samples came from the deepest layer region. Among nitrogen forms in waters, beside nitrate, we measured ammonium levels as well. Average $\mathrm{NH}_{4}{ }^{+}$concentrations were shown slightly increasing with deepness.

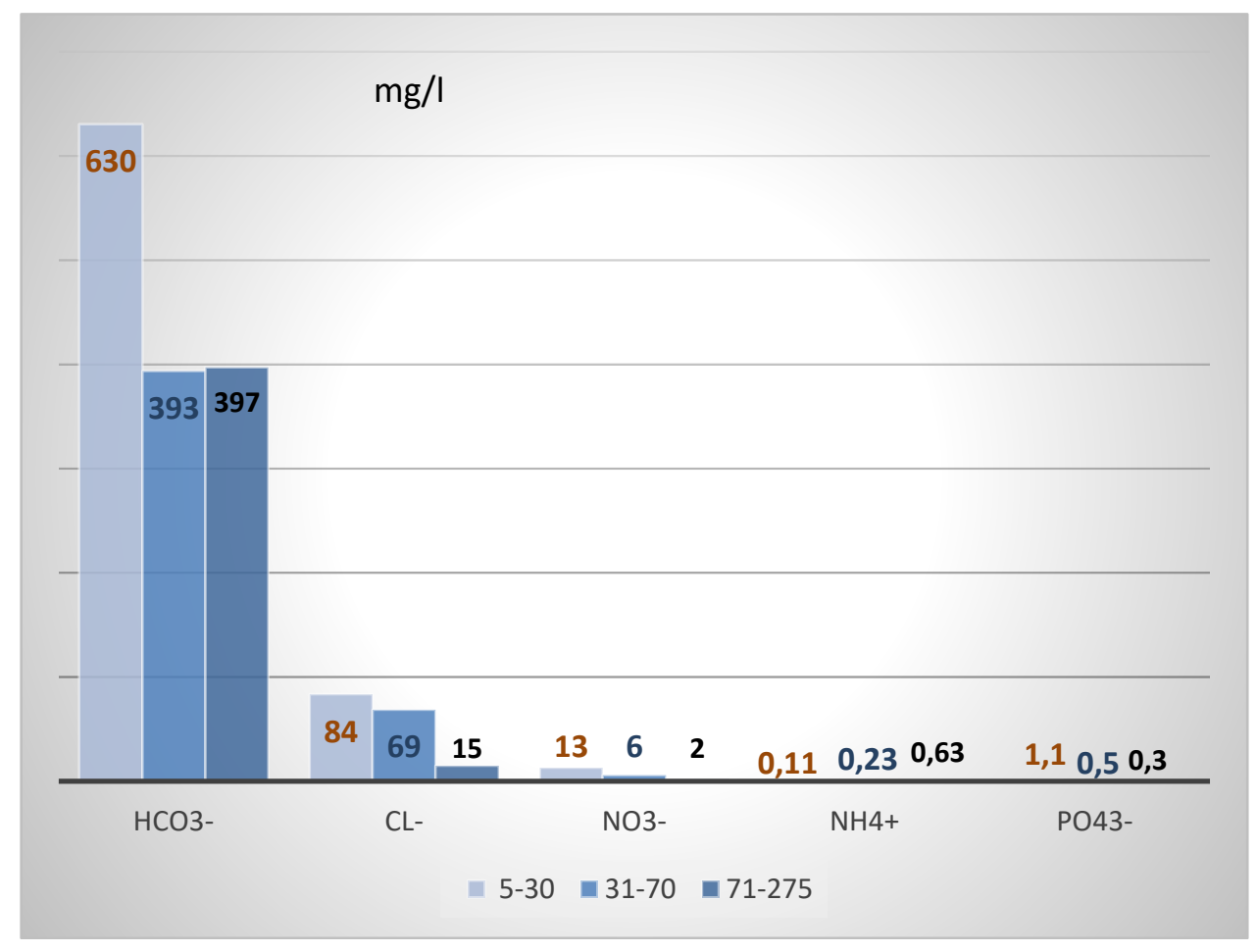

Figure 2. $\mathrm{HCO}_{3}{ }^{-}, \mathrm{Cl}, \mathrm{NO}_{3}-\mathrm{NH}_{4}^{+}$and $\mathrm{PO}_{4}{ }^{3-}$ levels in samples in three depth categories, expressed in average $\mathrm{mg} / \mathrm{l}$ concentration.

The occurrence of high anion values is shown in Table 3 . The value was called high over 500 $\mathrm{mg} / \mathrm{l}$ in the case of $\mathrm{HCO}_{3}{ }^{-}$, over $142 \mathrm{mg} / \mathrm{l}$ in the case of $\mathrm{Cl}^{-}$, over $50 \mathrm{mg} / \mathrm{l}$ in the case of $\mathrm{NO}_{3}^{-}$, over 30 $\mathrm{mg} / \mathrm{l}$ in the case of $\mathrm{PO}_{4}{ }^{3-}$ and $0.20 \mathrm{mg} / \mathrm{l}$ in the case of $\mathrm{NH}_{4}{ }^{+}$. 
$\mathrm{HCO}_{3}{ }^{-}$level showed an extremely high variation in the highest layer, and the ratio of the over $500 \mathrm{mg} / \mathrm{l}$ concentration exceeded $10 \%$ of the samples. It was the case with ammonium ion in the two deepest layers as well (Table 3.).

Nitrate and chloride contamination appeared primarily in the first group. Nitrate and chloride levels were in strong relation with soluble salt content $(p<0.01)$. We did not observe high phosphate levels in any waters.

Table 3. Occurrence of high values of the main anions and ammonium (expressed in \%) in different depths

\begin{tabular}{|c|c|c|c|}
\hline & $5-30 \mathrm{~m}$ & $31-70 \mathrm{~m}$ & $71-275 \mathrm{~m}$ \\
\hline & $\%$ & $\%$ & $\%$ \\
\hline $\mathrm{HCO}_{3}^{-}$ & 12.3 & 2.33 & 1.37 \\
\hline $\mathrm{Cl}^{-}$ & 6.85 & 4.11 & 0 \\
\hline $\mathrm{NO}_{3}{ }^{-}$ & 5.48 & 2.74 & 0 \\
\hline $\mathrm{NH}_{4}{ }^{+}$ & 0 & 15.1 & 42.8 \\
\hline $\mathrm{PO}_{4}{ }^{3-}$ & 0 & 0 & 0 \\
\hline
\end{tabular}

Main micro metallic ion contents were also observed. As a result, Fe content tended to be the highest in the middle deepness category, while Mn tended to decrease with depth (Fig. 3.). Iron ion concentration exceeded $500 \mu \mathrm{g} / \mathrm{l}$ for irrigation water in the three groups 9,34 and $4 \%$ of the samples, respectively. Regarding manganese 3,10 and $0 \%$ of the samples exceeded $300 \mu \mathrm{g} / \mathrm{l}$ level. Arsenic ion content is allowed to reach $100 \mu \mathrm{g} / \mathrm{l}$ in irrigation water for vegetables and fruit for human consumption. In our samples this limit was not exceeded in any samples of the present investigation.

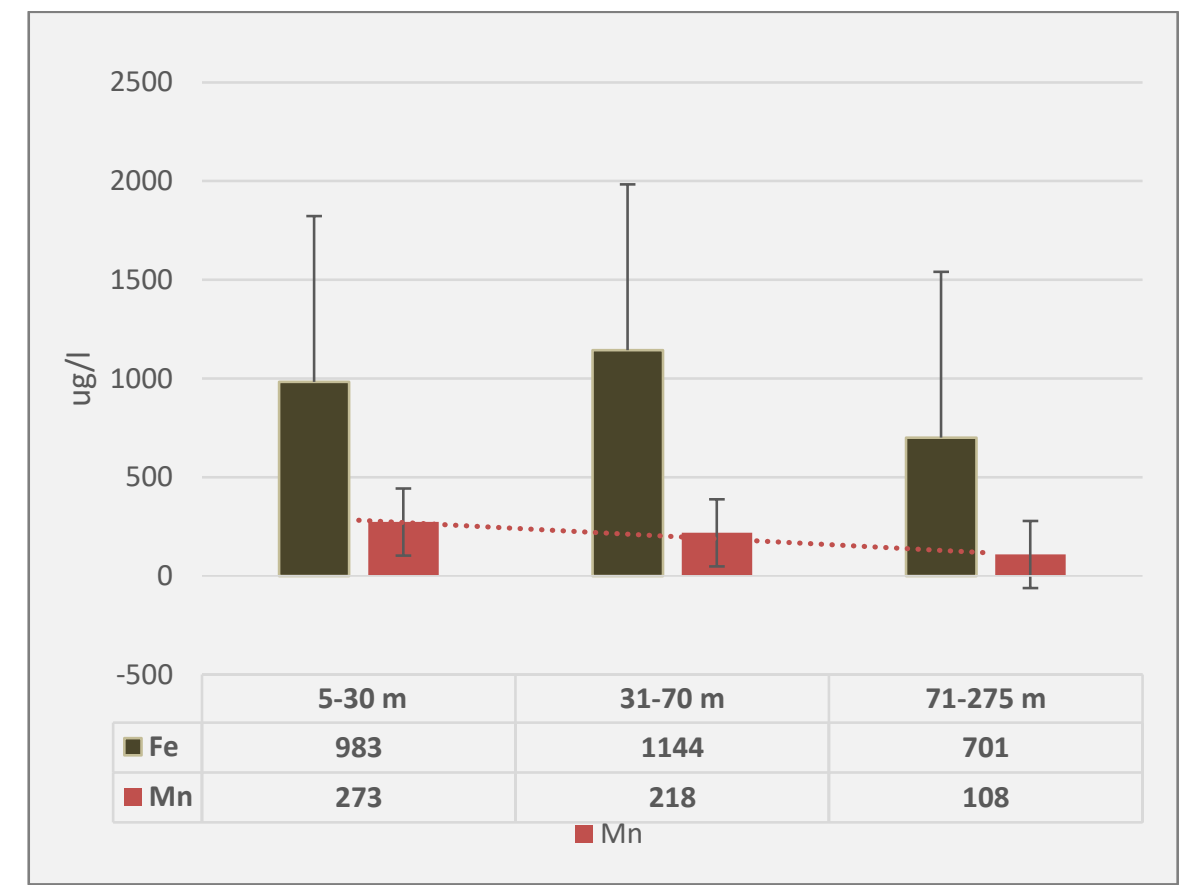

Figure 3. Fe and Mn levels in samples in three depth categories, expressed in average $\mu \mathrm{g} / \mathrm{l}$. 


\section{Discussion}

Depth of the investigated groundwater samples usually fell in the middle range category (31$75 \mathrm{~m}$ ) in our study. This well depth is the most common in our region as the appropriate quality aquifers are located at this depth. It is widespread for farmers to use their own wells for irrigation and/or liquid nutrient fertilization in horticulture growing.

In our laboratory we analyse groundwater samples for farmers regularly. In the present study we showed the results of 2016-2019 study period and compared them with the results of our former studies $[13,14] . \mathrm{pH}$ of the samples fell in the slightly alkaline range. Changes of the alkalinity with depth were not significant. Alkalinity exceeded slightly the limit offered for irrigation in only $2.67 \%$ of the samples. Alkalinity derived primarily from sodium and secondly from calcium ions. Large contamination of groundwater samples was shown in the upper deepness range in some cases. It was the case regarding $\mathrm{Na}^{+}$and $\mathrm{K}^{+}$among the main cations. Potassium levels were low in our former studies, but now we found a sample, derived from Kunszentmiklós, form 20 m depth, with extremely high $\mathrm{Na}^{+}$and $\mathrm{K}^{+}$, nitrate and chloride level. In our later studies we are on continuing the analysis of our data regarding the ratio of the main components, expressing especially the $\mathrm{Na} S \%$ and SAR value, which have special important role in irrigation water characteristic, as well [10, 22].

The level of the main cations and anions decreased with deepness (with one exception), indicating that soluble ion accessibility is naturally declining. Higher salt concentration was typical in the upper aquifers. It came from higher hydro-carbonate and chloride contents in most cases. These results are consistent with our previous experiences, and that groundwaters may be rich in hydrocarbonate and chloride in natural conditions as well [14].

Ammonium concentrations in the deepest groundwaters were higher, due to naturally anaerobic conditions. Pretreatment of deep-water sources commonly should contain ammonium removal techniques $[14,20]$.

We showed that nitrate content decreased with depth significantly in groundwater, and was in close correlation with soluble salt content, as well. In nitrate-sensitive areas, common in our region, the amount of organic fertilizer and the manure application period is also limited, and yet, farmers have to take into account the nutrient requirements and phenophases of the culture as well. Keeping the rules of the Good Agricultural Practice is mandatory in nitrate sensitive areas [21]. Farmers have to make soil tests regularly and have to control the quality of the irrigation water.

Due to the leaching losses, nitrate contamination in the environment could be expected $[3,4$, 19]. This can be justified by determining the nitrate leaching into the deeper soil layers or even its appearance in the groundwaters. In our study we showed that nitrate levels in the upper soil layers were in overlimit range in about $5 \%$ of the samples. In our former study we observed lower nitrate concentrations, about $2 \mathrm{mg} / \mathrm{l}$ dry matter in the average in the topsoil. Nevertheless, we should emphasize that organic fertilization is extremely important in sandy soils to balance nitrate and other nutrient levels in the soil [19]. Phosphorus contamination in waters was not significant in our present and former investigations either.

High Fe, Mn and As content in groundwaters is a common problem in the Duna-Tisza interfluve and surroundings. We showed extremely high levels of $\mathrm{Fe}$ and $\mathrm{Mn}$ in some waters deriving from some towns e.g. Nyársapát, Tiszaug and Kunszentmiklós. The extremely high Fe levels (up to 7000 $\mu \mathrm{g} / \mathrm{l}$ ) appeared in one-third of the samples, deriving from 31-70 m deepness. In our previous studies we showed the highest Fe concentration in the middle range. However, it cannot be ruled out that high ferrous concentration reflects sampling faults in some cases. Arsenic content in samples, fortunately, were not high, and lower than observed earlier [15]. Arsenic contents are often high in the south-eastern part of Hungary and contamination of sprinkling water may be hazardous in vegetable growing [9].

Pre-treatment of these sprinkling waters with nitric acid or phosphoric acid is far suggested avoiding precipitation of ferrous residue in mechanic irrigation components (primarily at trickle irrigation). Acidification is recommended to remove excess bicarbonate as well. Taking into account these results help us to use water resources economical for irrigation and avoiding threat to the environment. 


\section{Conclusion}

Our study emphasizes that analysis and economical use of irrigation water is essential for agricultural growing and activities. Due to irrigation development and adequate laboratory tests farmers probably reach higher yields and crop security increases. Nevertheless, to implement irrigation development, the simplification of the water permitting process by the authority is essential. On the other hand, quality of sprinkling water is far important factor. Our present results - with some minor exceptions - are in accordance with former statements regarding concentration of the main chemical components and physical characteristics of the irrigation ground waters.

\section{Acknowledgment}

Authors thank for the support of the research carried out in the framework of the EFOP-3.6.216-2017-00012 „Developing a functional, healthy and safe food product chain model from field to table in a thematic research network". The project is funded by the Hungarian State and the European Union, co-financed by the European Social Fund, and is part of the Széchenyi 2020 program.

\section{References}

[1] Balázs G., Csapó-Birkás Z., Geösel A., Hodossi S., Kecskeméti S., Szabó A., Zentai Á. (Ed: Terbe I., Slezák K.) (2019): Talaj nélküli zöldséghajtatás. Mezőgazda Lap- és Könyvkiadó, Budapest, 419. p. ISBN 978-963-286-7397

[2] Bauder, J. W., Brock T. A. (2001): Irrigation water quality, soil amendment, and crop effects on sodium leaching. Arid Land Research and Management 15. 2 pp. 101-113. https://doi.org/10.1080/15324980151062724

[3] Booltink, H. W. G. (1995). Field monitoring of nitrate leaching and water flow in a structured clay soil. Agriculture, ecosystems \& environment, 52. 2-3 pp. 251-261. https://doi.org/10.1016/0167-8809(94)00524-I

[4] Buzás, I., Hoyk, E., Cserni, I., Borsné Pető, J. (2006): Evaluation of the optimum nitrogen fertilizer depending on the nitrate content of the soil in sweet corn plantation. Cereal Research Communications 34. 1 pp. $421-424$. https://doi.org/10.1556/CRC.34.2006.1.105

[5] Cserni I. (2012): Talajaink vízgazdálkodása, növénykultúrák öntözése a Duna-Tisza közén. AGTEDU 2013 Tudományos Konferencia kiadványa. pp. 11-19.

[6] Filep Gy. (1999): Az öntözővíz minősége és minősítése. Agrokémia és talajtan 48. 1-2. pp. 49-65.

[7] Fisher, R. A., F. Yates (1963): Statistical Tables for Biological, Agricultural and Medical Research. 6th Ed. Oliver \& Boyd, Edinburgh and London, 10. 146 p., https://doi.org/10.1002/bimj.19710130413

[8] Horinka T. (2010): Kertészeti növények komplett tápanyagellátása, Kertészek kis/Nagy Áruháza Kft, Mórahalom, 526. p. ISBN 978-963-06-8970-0

[9] Hüvely, I. Buzás, J. Pető, Zs. Tóthné Taskovics, E. Hoyk (2013): Effects of arsenic contamination in sprinkling water on the arsenic content of lettuce in hydroculture. Review on Agriculture and Rural Development 2. 2 pp. 578-582. 12th Wellmann International Scientific Conference, Hódmezővásárhely, ISSN: 2063-4803

[10] Kallis, G., Butler, D. (2001): The EU water framework directive: measures and implications. Water policy 3. $2125-$ 142. DOI: 10.1016/S1366-7017(01)00007-1

[11] Kantoci, D. (2012): Navodnjavanje, Glasilo biljne zaštite. 3 pp. 66-72.

[12] Marosán Á. (2017): Statisztikai jelentések, Öntözésjelentés 2016. év, Szerk: Bábáné Demeter E., 20. 1. 17. p., ISSN 14182130

[13] Pereira, L. S., Oweis T., Zairi A. (2002): Irrigation management under water scarcity. Agricultural water management 57. 3 pp. 175-206. DOI: 10.1016/S0378-3774(02)

[14] Pető J., Hüvely A., Cserni I., Nagy J. (2011): A termálvíz összetételének jellemzése Kecskeméten. AGTEDU 2012. Tudományos Konferencia kiadványa, pp. 169-174. ISSN 1586-846X

[15] Petö, J., A. Hüvely, I. Cserni (2013): Results of analysis of irrigation water located mainly in county Bacs-Kiskun. Review on Agriculture and Rural Development 2. 2 pp. 545-549. 12th Wellmann International Scientific Conference, Hódmezővásárhely, ISSN: 2063-4803

[16] Petö, J., A. Hüvely, V. Vojnich, E.Hoyk (2016): Main characteristic composition of some ground and artesian waters in the south between Danube-Tisza Region of Hungary, Lucrari Stiintifice Management Agricol 18. 2 pp. 93-98. DOI: https://doi.org/10.1515/arls-2018-0023

[17] Petö, J., A. Hüvely, V. J. Vojnich (2017): Characterization of new fruit and grape plantations in the Southeastern part of Hungary. Journal of Processing and Energy in Agriculture 21. 3 pp. 178-180. Biblid: 1821-4487, UDK: 631.543 .8

[18] Pető J., Hüvely A., Vojnich V. J., Cserni I. (2017): Szőlöültetvény-telepítés előtti talajfizikai vizsgálatok értékelése a Duna-Tisza közén. Gradus 4. 2 pp. 156-161.

[19] Pető J., Hüvely A., Vojnich V. J., Cserni I. (2019) A talaj felvehető tápelemeinek összefüggése a vízoldható sótartalommal. Gradus 6. 2 pp. 33-38. 
[20] Van der Wielen, P. W., Voost, S., \& van der Kooij, D. (2009). Ammonia-oxidizing bacteria and archaea in groundwater treatment and drinking water distribution systems. Applied and Environmental Microbiology, 75.14 pp. 4687-4695. DOI: 10.1128/AEM.00387-09

[21] 59/2008. (IV. 29.) FVM rendelet $A$ vizek mezőgazdasági eredetű nitrátszennyezéssel szembeni védelméhez szükséges cselekvési program részletes szabályairól, valamint az adatszolgáltatás és nyilvántartás rendjéről.

[22] 90/2008. 90/2008. (VII. 18.) FVM rendelet A talajvédelmi terv készítésének részletes szabályairól.

[23] Ml-10-172/9-1990 Felszíni vizek minősége. Öntözővíz minőségének vizsgálati, értékelési és minősítési rendje. 